\title{
Combining Ability and Heterosis Studies for Grain Yield and Its Components in Hybrids of Quality Protein Maize (Zea mays L.)
}

\author{
Pandurang Arsode ${ }^{1 *}$, K. Murali Krishna ${ }^{2}$, N. Sunil ${ }^{3}$, Vani Sree ${ }^{4}$ and A. Ravi Charan ${ }^{2}$ \\ ${ }^{1}$ Department of Genetics and Plant Breeding, Institute of Agricultural Sciences, \\ Banaras Hindu University, Varanasi-Uttar Pradesh- 221005, India \\ ${ }^{2}$ Department of Genetics and Plant Breeding, College of Agriculture, \\ Rajendranagar, Telangana, India \\ ${ }^{3}$ Winter Nursery centre, IIMR, Rajendranagar, Telangana, India \\ ${ }^{4}$ Institute of Biotechnology, Rajendranagar, Telangana, India \\ *Corresponding author
}

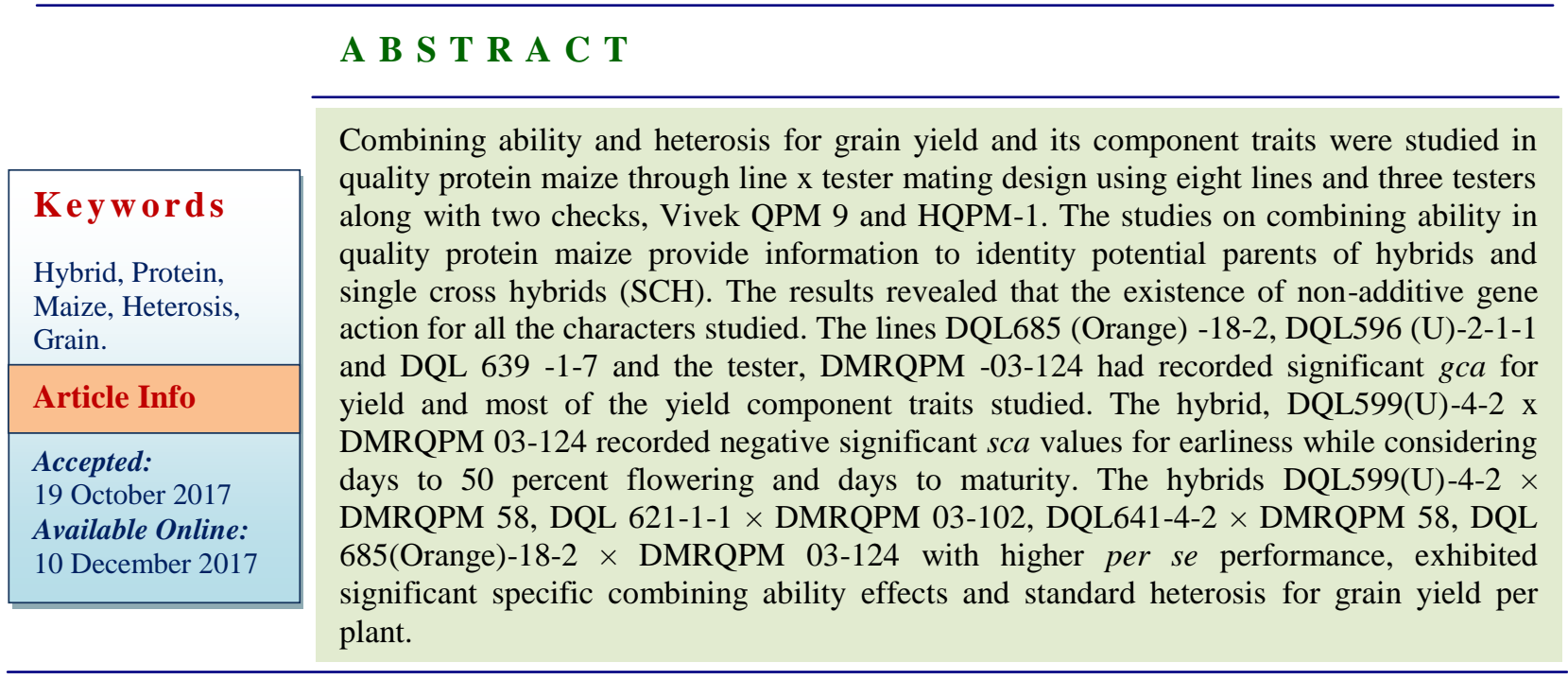

\section{Introduction}

Maize is the third most important cereal crop after wheat and rice and is considered one of the most versatile emerging crop having wider adaptability under varied agro-climatic conditions. With its high content of carbohydrates, fats, proteins and some of the important vitamins and minerals, maize acquired a well-deserved reputation as a 'poor man's nutricereal (Prasanna et al., 2001). In addition, it is a basic raw material for the production of starch, oil, protein, alcoholic beverages, food sweeteners, fuel and more importantly a model plant exhaustively researched in genetics. Globally, maize is known as "queen of cereals" because it has the highest genetic yield potential among the cereals. During 2015-16, globally maize was cultivated on an area of 178 million ha in about 160 countries with a total production of 1037 million tons (Foreign Agricultural Service, USDA, 2016). In India, the crop was grown on an area of 9.2 million ha with total production of 26.15 million metric tons with an average yield $3340 \mathrm{~kg} / \mathrm{ha}$. In Telangana 
state, it covers an area of 0.69 million hectares with a production of 2.31 million tonnes and productivity of $3340 \mathrm{~kg} \mathrm{ha}^{-1}$ (2014-15) (India Stat, 2015).

Maize is deficient in some essential amino acids such as lysine and tryptophan, provitamin $\mathrm{A}$ and in micronutrients such as iron, zinc and calcium whose bioavailability is significantly lowered due to chelators such as phytate which is indigestible by monogastric animals, including humans (Sun et al., 2009). As cereal proteins, however have poor nutritional value because of reduced content of essential amino acids such as lysine, tryptophan. To overcome these problems, decades of efforts by researchers at International Maize and Wheat Improvement Centre (CIMMYT) led to the development of lines with enhanced nutritional values which were designated as "Quality Protein Maize" or QPM lines (Vasal et al., 1980). The conventional breeding procedures helped in releasing several QPM hybrids both in Africa and Latin America. India has imported the Mexican QPM lines and developed several QPM hybrids in recent past. However, it is very much essential to develop the QPM hybrids which can yield on par with normal hybrids. Therefore, the present investigation was carried out to identify superior QPM hybrids.

\section{Materials and Methods}

Eight inbred lines were crossed with three inbred testers in a line $\mathrm{x}$ tester mating design in summer, 2015 to generate 24 crosses. All the 24 crosses and two standard checks Vivek QPM-9 and HQPM-1and parents (lines and testers) were evaluated during kharif, 2016 at Winter Nursery Center (ARI), Rajendranagar, Hyderabad, Telangana State. Each genotype was grown in three rows of four meters length with $60 \times 20 \mathrm{~cm}^{2}$ spacing in a randomized block design with three replications. The trial was conducted in a sandy loam soils. All the recommended agronomic practices were followed to raise a normal crop. Data were recorded on five randomly selected plants in each treatment for thirteen characters viz., days to 50 per cent tasseling, days to 50 per cent silking, days to maturity, plant height, ear height, ear length, ear diameter, number of kernel rows per ear, number of kernels per row, 100-seed weight, shelling percentage, protein content and grain yield per plant. The data collected were subjected to analysis of variance as suggested by Panse and Sukhatme (1985). The combining ability analysis was done according to Kempthorne (1957) and heterosis by Virmani et al., (1982).

\section{Results and Discussion}

The analysis of variance for combining ability for grain yield and yield components in quality protein maize are presented in Table 1.

The analysis of variance for combining ability revealed that genotypes exhibited highly significant differences among themselves. Mean sum of squares for combining ability for grain yield and its components in QPM showed that there were significant differences for all the characters except days to $50 \%$ tasseling, number of kernel rows per ear and number of kernels per row in hybrids. When the effects of crosses was partitioned into lines, testers and line $\times$ tester effects, the lines recorded non-significant differences for all the characters except shelling percentage. In testers, the mean sum of squares was positively non-significant for all the characters except days to $50 \%$ silking and protein content $(\%)$. The interaction effects (lines $\times$ testers) were found to be significant for maturity, plant height, ear height, ear length, ear girth, 100-seed weight, shelling percentage, protein content (\%) and grain yield per plant. Thus it reveals the presence of 
significant variability in the material studied. Components of genetic variation revealed that the estimates of SCA variance were greater than GCA variance for all the characters studied suggesting the predominance of nonadditive gene action in expression of various characters. This showed the possibility of exploiting these traits through heterosis breeding. This was further confirmed as $\sigma^{2}$ gca/ $\sigma^{2}$ sca ratio is less than unity for all the characters. Similar results were reported by Bupesh Kumar et al., (2015).

Additive component of genetic variance is fixable through normal selection procedures, where as non-additive component is not fixable and its presence for the controlling traits necessitates exploitation of hybrid vigour through heterosis breeding. Ravi and Chikkalingaiah (2012) and Jain and Bharadwaj (2014) also identified good general combiners and superior hybrids in quality protein maize. In the present study, the line, DQL685 (Orange) -18-2 and tester DMRQPM-58 possessed low per se and turned out to be good general combiners for days to flowering and maturity and contributed maximum favourable genes for earliness. Thus, they can be used as potential donors for inducing earliness. Similar results were reported by Bhavana et al., (2011) and Haydar et al., (2014) who reported additive gene action for days to 50 per cent flowering.

The lines, DQL685 (Orange) - 18-2 for flowering, protein content and grain yield per plant, DQL596 (U) -2-1-1 for plant height, ear height, ear length, shelling percentage, protein content and grain yield per plant, DQL 639 1-7 for kernel rows per ear, shelling percentage, protein content and grain yield per plant were the best combiner with significant gca effect contributed maximum favorable genes. Similar results were reported by Ravi and Chikkalingaiah (2012) and Jain and Bharadwaj (2014).
Grain yield is a complex character and is influenced by number of component traits. DQL 685 (Orange)-18-2 registered high mean grain yield and was also a good combiner as evidenced by its significant gca effects suggesting that for improving grain yield, this parent would play a key role. Such good combiner could also be intercrossed among the genotypes so as to develop high yielding composites (Table 2). The parents with high gca could produce superior segregates in the $\mathrm{F}_{2}$ as well as in later generations. Jebaraj et al., (2010) emphasized that the selection of parents with good $g c a$ was a prime requisite for any successful breeding programme especially for heterosis breeding.

The sca effects are the manifestation of nonadditive components of genetic variation and are highly valuable for discrimination of crosses for their genetic worth as breeding material. The significance of sca effects elucidates the presence of genetic diversity among the breeding material tested and illustrated the contribution of dominance and epistatic effects which is non fixable in nature and is a chief cause of heterosis. Earliness is a desirable character as these hybrids mature early and mostly suited for rainfed and low rainfall areas and also intercropping. In the present investigation also, the crosses, DQL 621-1-1 x DMRQPM 58 and DQL641-4-2 x DMRQPM-58 exhibited significant negative sca for earliness and is resultant of nonadditive gene action which could be improved through suitable population improvement programme in addition to utilizing them in heterosis breeding. Similar results were in conformity with of Praveen Kumar et al., (2014), Rajitha et al., (2014) and Bupesh Kumar et al., (2015) who reported nonadditive gene action for days to maturity. The cross, DQL599(U)-4-2 x DMRQPM 03-124 recorded negative significant sca effects for days to $50 \%$ tasseling and days to $50 \%$ silking. 


\section{Int.J.Curr.Microbiol.App.Sci (2017) 6(12): 2538-2545}

Table.1 Analysis of variance for combining ability for grain yield and its component characters in quality protein maize

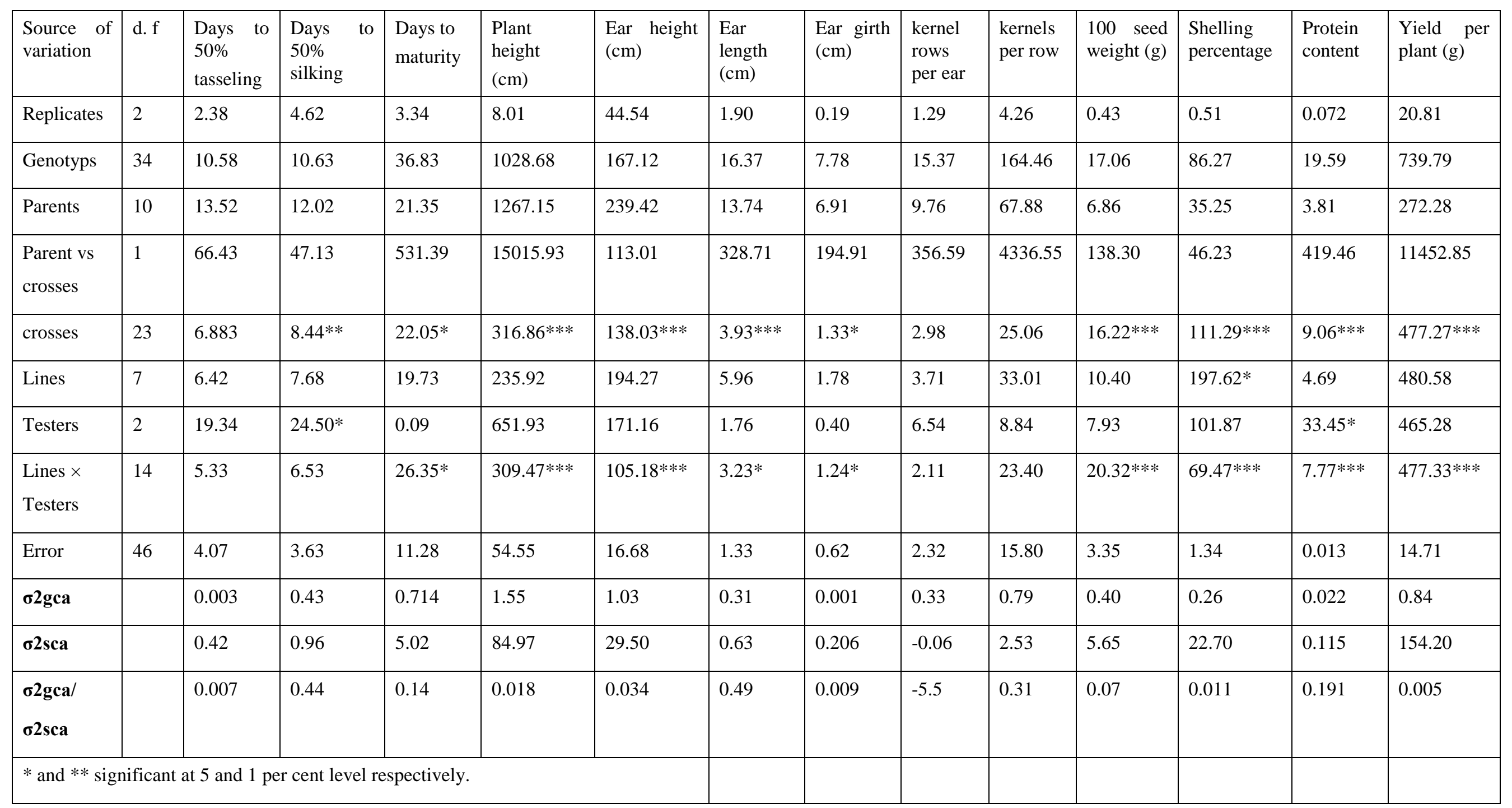


Table. 2 Top ranking cross combinations based on Per se performance, SCA, GCA effects and Heterosis

\begin{tabular}{|c|c|c|c|c|c|}
\hline Characters & \multicolumn{2}{|c|}{ Good general combiners } & Per se performance of the best crosses & Good specific combiners & Heterotic combinations \\
\hline & Lines & Testeres & & & \\
\hline $\begin{array}{l}\text { Days to } 50 \% \\
\text { tasseling }\end{array}$ & $\begin{array}{l}\text { DQL } 685 \text { (Orange) -18- } \\
2(1.20)\end{array}$ & $\begin{array}{l}\text { DMRQPM-58 } \\
\left(-0.93^{*}\right)\end{array}$ & $\begin{array}{l}\text { DQL505(Orange)-2-1 × DMRQPM } \\
58 \text { (50) }\end{array}$ & $\begin{array}{l}\text { (DQL599 (U)-4-2 x DMRQPM } \\
03-124)(-2.62 *)\end{array}$ & $\begin{array}{l}\text { 1. DQL 599(U)-4-2 × DMRQPM } 58 \\
\left(7.84^{* *}\right) \\
\text { 2. DQL 621-1-1 × DMRQPM 03- } \\
102\left(8.50^{* *}\right)\end{array}$ \\
\hline $\begin{array}{l}\text { Days to } 50 \% \\
\text { silking }\end{array}$ & $\begin{array}{l}\text { DQL } 685 \text { (Orange) -18- } \\
2\left(1.40^{*}\right)\end{array}$ & DMRQPM-58(1.08) & $\begin{array}{l}\text { DQL505(Orange)-2-1 × DMRQPM } \\
58 \text { (52) }\end{array}$ & $\begin{array}{l}\text { DQL599 (U)-4-2 x DMRQPM } \\
\text { 03-124 (2.94*) }\end{array}$ & $\begin{array}{l}\text { 1.DQL599(U)-4-2 × DMRQPM 03- } \\
\text { 102(8.81**) } \\
\text { 2.DQL 621-1-1 × DMRQPM 03- } \\
\text { 102(10.69**) }\end{array}$ \\
\hline Days to maturity & $\begin{array}{l}\text { DQL 685 (Orange) -18- } \\
2(1.97)\end{array}$ & $\begin{array}{l}\text { DMRQPM - } \\
58(0.05)\end{array}$ & DQL 621-1-1 x DMRQPM-58 (102) & $\begin{array}{l}\text { 1. DQL 621-1-1 x DMRQPM- } \\
\text { 102(-5.26**) 2.DQL641-4-2 } \\
\text { DMRQPM-58(-4.61*) }\end{array}$ & $\begin{array}{l}\text { DQL599(U)-4-2 × DMRQPM } \\
58(11.91 * *)\end{array}$ \\
\hline Plant height $(\mathrm{cm})$ & $\begin{array}{l}\text { 1. DQL596 (U) -2-1-1 } \\
\left(7.91^{* *}\right) \\
\text { 2. DQL } 639-1-7\left(5.47^{*}\right)\end{array}$ & $\begin{array}{l}\text { DMRQPM-03- } \\
124(5.77 * *)\end{array}$ & $\begin{array}{l}\text { 1.DQL599(U)-4-2×DMRQPM 03- } \\
\text { 102 (108.33) } \\
\text { 2.DQL641-4-2×DMRQPM-03- } \\
\text { 124(140) } \\
\text { 3.DQL596(U)-2-1-1 × DMRQPM 03- } \\
\text { 124(138.33) }\end{array}$ & $\begin{array}{l}\text { 1.DQL599(U)-4-2 x DMRQPM } \\
\text { 03-102 (10.23*) } \\
\text { 2.DQL641-4-2 x DMRQPM-03- } \\
\text { 124(12**) } \\
\text { 3.DQL596(U)-2-1-1× DMRQPM } \\
\text { 03-124 (9.77*) }\end{array}$ & $\begin{array}{l}\text { 1.DQL596(U)-2-1-1 × DMRQPM } \\
\text { 03-124(11.70**) } \\
\text { 2.DQL641-4-2 × DMRQPM 03- } \\
\text { 124(11.70**) }\end{array}$ \\
\hline Ear height $(\mathrm{cm})$ & DQL596 (U) -2-1-1(8.4**) & $\begin{array}{l}\text { DMRQPM-03- } \\
124\left(2.58^{* *}\right)\end{array}$ & $\begin{array}{l}\text { 1.DQL685(Orange)-18-2 } \times \\
\text { DMRQPM 58(63.33) } \\
\text { 2.DQL 621-1-1 × DMRQPM } \\
\text { 58(62.33) } \\
\text { 3.DQL599(U)-4-2 × DMRQPM 03- } \\
\text { 102(60.67) }\end{array}$ & $\begin{array}{l}\text { 1.DQL596(U)-2-1-1× } \\
\text { DMRQPM 03-124(6.75*) } \\
\text { 2.DQL599(U)-4-2 × DMRQPM } \\
\text { 03-102(6.75*) } \\
\text { 3.DQL641-4-2 × DMRQPM 03- } \\
\text { 124(7.00*) }\end{array}$ & $\begin{array}{l}\text { DQL 621-1-1 × DMRQPM 03- } \\
\text { 102(2.15) }\end{array}$ \\
\hline Ear length $(\mathrm{cm})$ & DQL596 (U) -2-1-1(1.60**) & $\begin{array}{l}\text { DMRQPM - } \\
58(0.26)\end{array}$ & $\begin{array}{l}\text { 1.DQL 621-1-1 x DMRQPM 03- } \\
\text { 102(15.03) } \\
\text { 2.DQL 685(Orange)-18-2 x } \\
\text { DMRQPM 03-124(15.67) }\end{array}$ & Nil & $\begin{array}{l}\text { 1.DQL 639-1-7 × DMRQPM } \\
\text { 58(23.59**) } \\
\text { 2.DQL 621-1-1 × DMRQPM 03- } \\
\text { 124(32.05**) } \\
\text { 3. DQL641-4-2 } \times \\
\text { DMRQPM }(5.13 * *) \\
\text { 4.DQL599(U)-4-2 × DMRQPM } \\
\text { 58(8.97**) }\end{array}$ \\
\hline Ear girth $(\mathrm{cm})$ & $\begin{array}{l}\text { 1.DQL505 (Orange) -2- } \\
\text { 1(0.56) } \\
\text { 2.DQL } 639-1-7(0.40)\end{array}$ & DMRQPM-58(0.12) & $\begin{array}{l}\text { 1.DQL 685(Orange)-18-2 x } \\
\text { DMRQPM 03-124(12.97) } \\
\text { 2.DQL505(Orange)-2-1× DMRQPM } \\
\text { 58(13.33) }\end{array}$ & Nil & $\begin{array}{l}\text { 1.DQL505(Orange)-2-1× } \\
\text { DMRQPM } 58 \\
\text { 2.DQL505(Orange)-2-1 } \times \\
\text { DMRQPM 03-102(15.61**) }\end{array}$ \\
\hline
\end{tabular}


Int.J.Curr.Microbiol.App.Sci (2017) 6(12): 2538-2545

\begin{tabular}{|c|c|c|c|c|c|}
\hline & $\begin{array}{l}\text { 3.DQL 565(U)-3-1(Orange) } \\
(0.54)\end{array}$ & & & & $\begin{array}{l}\text { 3.DQL 685(Orange)-18-2× } \\
\text { DMRQPM 03-124(12.43**) } \\
\text { 4.DQL641-4-2 } \times \text { DMRQPM }(5.2 * *)\end{array}$ \\
\hline $\begin{array}{l}\text { Kernel rows per } \\
\text { ear }\end{array}$ & Nil & Nil & $\begin{array}{l}\text { 1.DQL 685(Orange)-18-2 x } \\
\text { DMRQPM 03-124(15.33) }\end{array}$ & Nil & $\begin{array}{l}\text { 1.DQL505(Orange)-2-1 } \times \\
\text { DMRQPM 58(4.55**) }\end{array}$ \\
\hline Kernels per row & DQL $639-1-7\left(3.50^{* *}\right)$ & $\begin{array}{l}\text { DMRQPM-03-102 } \\
\left(0.86^{*}\right)\end{array}$ & $\begin{array}{l}\text { 1.DQL 621-1-1 x DMRQPM 03- } \\
\text { 102(37) } \\
\text { 2.DQL 685(Orange)-18-2 x } \\
\text { DMRQPM 03-124(38) }\end{array}$ & Nil & $\begin{array}{l}\text { 1.DQL 621-1-1 × DMRQPM 03- } \\
\text { 102(19.35**) } \\
\text { 2. DQL 685(Orange)-18-2× } \\
\text { DMRQPM 03-124(22.58**) } \\
\text { 3.DQL641-4-2 } \times \\
\text { DMRQPM }\left(5.38^{* *}\right)\end{array}$ \\
\hline $\begin{array}{l}100 \text { seed weight } \\
(\mathrm{g})\end{array}$ & Nil & $\begin{array}{l}\text { DMRQPM -03- } \\
102(0.91 *)\end{array}$ & $\begin{array}{l}\text { 1.DQL 621-1-1 x DMRQPM 03- } \\
\text { 102(31.33) } \\
\text { 2.DQL599(U)-4-2 x DMRQPM } \\
\text { 58(32.33) }\end{array}$ & $\begin{array}{l}\text { 1.DQL599(U)-4-2 × DMRQPM } \\
\text { 58 (4.45**) } \\
\text { 2.DQL 621-1-1 x DMRQPM 03- } \\
\text { 102(3.88**) } \\
\text { 3.DQL685(ORANGE)-18-2 } \times \\
\text { DMRQPM 03-124 }\left(2.65^{*}\right)\end{array}$ & $\begin{array}{l}\text { 1.DQL505(Orange)-2-1 } \times \\
\text { DMRQPM 58(13.92**) } \\
\text { 2.DQL599(U)-4-2 } \times \text { DMRQPM } \\
\text { 58(22.78**) } \\
\text { 3. DQL641-4-2 } \times \\
\text { DMRQPM }(12.66 * *)\end{array}$ \\
\hline $\begin{array}{l}\text { Shelling } \\
\text { percentage }\end{array}$ & $\begin{array}{l}\text { DQL } 639-1-7(3.83 * *), \\
\text { (DQL596 (U) 2-1-1(2.34**) }\end{array}$ & Nil & $\begin{array}{l}\text { 1.DQL 621-1-1 x DMRQPM 03- } \\
\text { 102(88.91) } \\
\text { 2.DQL 685(Orange)-18-2 X x } \\
\text { DMRQPM 03-124(88.99) }\end{array}$ & $\begin{array}{l}\text { 1.DQL505(Orange)-2-1 } \times \\
\text { DMRQPM 03-102 }\left(1.99^{* *}\right) \\
\text { 2.DQL599(U)-4-2 } \text { DMRQPM } \\
\text { 58 }(12.06 * *) \\
\text { 3.DQL 565(U)-3-1 (Orange) } \times \\
\text { DMRQPM 03-102 }\left(3.15^{* *}\right)\end{array}$ & $\begin{array}{l}\text { 1.DQL 685(Orange)-18-2 } \times \\
\text { DMRQPM 58(6.14**), } \\
\text { 2.DQL 685(Orange)-18-2× } \\
\text { DMRQPM 03-124(6.79**) } \\
\text { 3.DQL641-4-2 } \times \\
\text { DMRQPM(4.54**) } \\
\text { 4. DQL599(U)-4-2 } \times \text { DMRQPM } \\
\text { 58(4.56**) }\end{array}$ \\
\hline Protein content & $\begin{array}{l}\text { 1.DQL } 639-1-7\left(0.46^{* *}\right) \\
\text { 2.DQL } 685 \text { (Orange) -18- } \\
\text { 2(1.07**) } \\
\text { 3.DQL596 (U) -2-1-1 } \\
\left(0.31^{* *}\right)\end{array}$ & $\begin{array}{l}\text { DMRQPM-03- } \\
124\left(1.35^{* *}\right)\end{array}$ & $\begin{array}{l}\text { 1.DQL599(U)-4-2 × DMRQPM 03- } \\
\text { 124(13.15) } \\
\text { 2. DQL 639-1-7 × DMRQPM 03- } \\
\text { 102(13.01) }\end{array}$ & $\begin{array}{l}\text { 1.DQL 685(Orange)-18-2 } \times \\
\text { DMRQPM 03-124 }\left(0.30^{* *}\right) \\
\text { 2.DQL 639-1-7 × DMRQPM 03- } \\
\text { 102 }(2.26 * *) \\
\text { 3DQL641-4-2 × DMRQPM } 58 \\
\left(0.45^{* *}\right)\end{array}$ & $\begin{array}{l}\text { 1.DQL599(U)-4-2 × DMRQPM } 03 \\
\text { 124(9.49**) } \\
\text { 2.DQL596(U)-2-1-1 × DMRQPM } \\
\text { 03-102(27.50**) }\end{array}$ \\
\hline $\begin{array}{l}\text { Yield per plant } \\
\text { (g) }\end{array}$ & $\begin{array}{l}\text { 1.DQL685 (Orange)-18- } \\
2\left(8.29^{* *}\right)\end{array}$ & $\begin{array}{l}\text { DMRQPM -03- } \\
124(5.77 * *)\end{array}$ & $\begin{array}{l}\text { 1. DQL599(U)-4-2 × DMRQPM } \\
\text { 58(97.17) } \\
\text { 2. DQL 621-1-1 x DMRQPM 03- } \\
\text { 102(99.27) } \\
\text { 3. DQL641-4-2 × DMRQPM } \\
\text { 58(99.33) } \\
\text { 4. DQL 685(Orange)-18-2 X } \\
\text { DMRQPM 03-124(96) }\end{array}$ & $\begin{array}{l}\text { 1..DQL599(U)-4-2 × DMRQPM } \\
\text { 58(4.85*) } \\
\text { 2.DQL 621-1-1 × DMRQPM 03- } \\
\text { 102(11.09**) } \\
\text { 3.DQL641-4-2 × DMRQPM } \\
\text { 58(12.71**) } \\
\text { 4. DQL 685(Orange)-18-2 X } \\
\text { DMRQPM 03-124(17.66**) }\end{array}$ & $\begin{array}{l}\text { 1.DQL599(U)-4-2 × DMRQPM } \\
\text { 58(16.61**) } \\
\text { 2.DQL 621-1-1 × DMRQPM 03- } \\
\text { 102(19.12**) } \\
\text { 3.DQL641-4-2 × DMRQPM } \\
\text { 58(19.20**) } \\
\text { 4. DQL 685(Orange)-18-2 X } \\
\text { DMRQPM 03-124(15.20**) }\end{array}$ \\
\hline
\end{tabular}


The crosses DQL 596(U)-2-1-1 x DMRQPM 03-124, DQL599 (U)-4-2 x DMRQPM 03102 and DQL641-4-2 x DMRQPM 03-124 exhibited significant positive sca effect for plant height, ear height. The crosses, DQL641-4-2 $\times$ DMRQPM 58 and DQL 685(Orange)-18-2 $\times$ DMRQPM 03-124 recorded significant positive significant sca effects for protein content and grain yield per plant. These hybrids exhibited 15.20 and 19.20 per cent superiority of grain yield over the check hybrid, Vivek QPM 9. Many of the crosses were from either one of the parents with high and significant $\mathrm{gca}$ and hence these crosses could be utilized for heterosis breeding. Further, Jebaraj et al., (2010) reported that the expression of high positive sca effects might be due to dominant $\mathrm{x}$ recessive interactions. These hybrids were expected to produce desirable segregants in the subsequent generations and could also be improved through recombination breeding.

The commercial hybrid, Vivek QPM 9 was used as a standard check. The hybrids, DQL 599(U)-4-2 × DMRQPM 58 had significant standard heterosis for maturity, DQL596 (U)2-1-1 × DMRQPM 03-124 for plant height. The crosses DQL641-4-2 × DMRQPM-58, DQL 621-1-1 × DMRQPM 03-102, DQL599 $(\mathrm{U})-4-2 \times$ DMRQPM 58 and DQL 685(Orange)-18-2 $\times$ DMRQPM 03-124 recorded significant positive standard heterosis of $19.20,19.12,16.61$, and 15.20 respectively for grain yield. The cross, DQL641-4-2 × DMRQPM -58 showed significant standard heterosis for grain yield which was accompanied by significant standard heterosis in ear length, ear girth, number of kernel rows per ear, number of kernels per row, 100 seed weight and shelling percentage. In cross DQL599(U)-4-2 × DMRQPM 58, the significant standard heterosis for grain yield was accompanied by significant standard heterosis in days to 50 per cent tasseling, days to 50 per cent silking, days to maturity, ear length, 100 seed weight and shelling percentage and protein content. Patel et al., (2016), Malik et al., (2004) and Vijay Bhaskar Reddy (2007) recorded positive significant standard heterosis for grain yield per plant in maize.

To develop a commercial hybrid, per se performance, sca effects and the extent of heterosis are chiefly considered (Murali Krishna et al., 2012). In the present study also, the hybrids were evaluated on the basis of the above said three parameters. Among the 24 hybrids, DQL599(U)-4-2 × DMRQPM 58, DQL 621-1-1 × DMRQPM 03-102, DQL641-4-2 × DMRQPM 58, DQL 685(Orange)-18-2 × DMRQPM 03-124 had significant per se performance, sca effects and standard heterosis for grain yield and its contributing characters (Table 2). These hybrids are of considerable practical importance which was proved to be superior over popular commercial hybrid, Vivek QPM 9. These crosses may be advanced for isolation of homozygous inbred lines for use in breeding programmes or may be used as single cross hybrids after evaluation in multilocation trials.

\section{References}

Bhavana, P., Singh, R.P and Gadag, R.N. 2011. Gene action and heterosis for yield and yield components in maize (Zea mays L.). Indian Journal of Agricultural Sciences. 81 (2): 163-6.

Bupesh Kumar, Razdan, A.K and Pandey, S. K. 2015. Combining ability analysis for grain yield and component traits in yellow maize single crosses. Bioinfolet. 12 (1A): 14-18.

Jain,R.and Bharadwaj, D.N.2014. Combining ability analysis for yield Quality Protein Maize (Zea mays L.).Agricultural Communications. 2(2):1-8.

Jebaraj, S., Selva Kumar, A and Shanthi, P 
2010. Study of gene action in quality protein maize hybrids. Indian Journal of Agriculture Research. 44 (2): 136-140.

Kempthorne, O. 1957. An Introduction to Genetic Statistics. John Wiley and Sons, INC., New York, pp.458-71.

Malik, H.N., Malik, S.I., Chughati, S.R and Javed, H.I. 2004. Estimates of heterosis among temperate, sub-tropical and tropical maize germplasm. Asian Journal of Plant Sciences. 3(1): 6-10.

Murali Krishna, K., Ranga Reddy, R and Sai Kumar R 2012 Heterosis and Combining ability for yield and its traits in quality protein maize (Zea mays L.). Quality protein maize Journal I(1): 4045 (April 2012).

Panse, V.G and Sukhatme, P.V. 1985. Statistical methods for agricultural workers, Indian Council of Agricultural Research, New Delhi.

Patel, P.C. and Kathiria, K.B.2016 Heterosis and combining ability for yield and quality traits in Quality Protein maize
(Zea mays L.). Electronic Journal Of Plant Breeding. 7(4):960-966.

Prasanna, B.M., Vasal, S. K., Kassahun, B and Singh N.N.2001.Quality Protein Maize ((Zea mays L.) Current Sciences. 81(10).

Rajitha, A., Ratna Babu, D., Lal Ahamed, M and Srinivasa Rao, V. 2014. Heterosis and Combining ability for grain yield and yield component traits in maize (Zea mays L.). Electronic Journal of Plant Breeding. 5(3): 378-384.

Ravi, M., Chikkalingaiah and Shailaja, H. 2012. Correlation study for protein content, grain yield and yield contributing traits in quality protein maize (Zea mays L.). Electronic Journal of Plant Breeding. 3(1): 649651

Virmani, S.S., Aquino, R.O and Khush, G.S. 1982. Heterosis breeding in Rice (Oryza sativa L.). Theoretical and Applied Genetics. 63: 373-380.

\section{How to cite this article:}

Pandurang Arsode, K. Murali Krishna, N. Sunil, Vani Sree and Ravi Charan, A. 2017. Combining Ability and Heterosis Studies for Grain Yield and Its Components in Hybrids of Quality Protein Maize (Zea mays L.). Int.J.Curr.Microbiol.App.Sci. 6(12): 2538-2545. doi: https://doi.org/10.20546/ijcmas.2017.612.294 